\title{
Hubungan Pola Kebersihan Diri Dengan Terjadinya Gangguan Kulit Pada Petani Padi
}

\section{Septina Riyansari ${ }^{1}$, Irdawati ${ }^{2 *}$}

1Universitas Muhammadiyah Surakarta, Surakarta 57162, Jawa Tengah, Indonesia

2Departemen Keperawatan Anak, Universitas Muhammadiyah Surakarta, Surakarta 57162, Jawa

Tengah, Indonesia.

* Korespodensi: irdawati@ums.ac.id

\begin{abstract}
Abstrak: Salah satu pekerjaan yang rentan terhadap gangguan kulit adalah petani. Sehinggga diperlukan penelitian untuk melihat pola kebersihan diri pada petani. Tujuan penelitian ini adalah untuk mengetahui hubungan antara pola kebersihan diri dengan terjadinya gangguan kulit pada petani padi di Kelurahan nanggulan Wilayah Kerja Puskesmas Cawas I Kecamatan Cawas Kabupaten Klaten. Penelitian ini merupakan penelitian kuantitatif non exsperimental yaitu survei analitik dengan rancangan cross sectional. Populasi dalam penelitian ini adalah 767 orang dan sampel diperoleh 89 responden. Pengambilan sampel dilakukan dengan teknik stratified random sampling dengan cara proporsional random sampling. Dari hasil menunjukkan adanya hubungan yang signifikan antara pola kebersihan diri dengan terjadinya gangguan kulit dengan $P$-value 0,001 dan $X^{2}=10,426$. Kesimpulan penelitian ini adalah terdapat hubungan antara pola kebersihan diri dengan terjadinya gangguan kulit pada petani padi di Kelurahan Nanggulan Wilayah Kerja Puskesmas Cawas I Kecamatan Cawas Kabupaten Klaten.
\end{abstract}

Kata Kunci: petani, pola kebersihan diri, gangguan kulit

Abstract: One of the jobs that is vulnerable to skin disorders is farmers. So that research is needed to see patterns of personal hygiene in farmers. The purpose of this study was to determine the relationship between patterns of personal hygiene with the occurrence of skin disorders in rice farmers in the Nanggulan Village Work Area Cawas I Health Center, Cawas District, Klaten Regency. This research is a non-experimental quantitative research that is an analytic survey with cross sectional design. The population in this study was 767 people and the sample obtained by 89 respondents. Sampling is done by stratified random sampling technique by proportional random sampling. From the results showed a significant relationship between patterns of personal hygiene with the occurrence of skin disorders with a P-value of 0.001 and $=10.426$. The conclusion of this study is that there is a relationship between patterns of personal hygiene with the occurrence of skin disorders in rice farmers in the Nanggulan

Keywords: farmers, personal hygiene patterns, skin disorders 


\section{PENDAHULUAN}

Di Indonesia jumlah angkatan kerja yang bekerja dibidang pertanian pada bulan Agustus 2014 berdasarkan data dari Badan Pusat Statistik berjumlah sekitar 34\%. Dibandingkan hasil sensus pertanian 2003 (ST2003) jumlah rumah tangga usaha pertanian hasil ST2013 menurun sebanyak 16, 32\% (BPS, 2014). Dibidang pertanian kesehatan dan keselamatan kerja juga perlu diperhatikan, mengingat standar penggunaan alat dan obat-obatan belum sesuai dengan anjuran. Berdasarkan data yang diperoleh dari database ASEAN OSHANET dan ILO dalam Haerani (2010), kecelakaan kerja di Indonesia yang terjadi di industri pertanian menduduki tempat kedua atau ketiga terbesar dibanding industri lain.

Kecelakaan akibat pestisida pada petani sering terjadi. Mereka dapat mengalami pusing-pusing ketika sedang menyemprot maupun sesudahnya, atau muntah-muntah, mulas, mata berair, kulit terasa gatal- gatal dan menjadi luka, kejang- kejang, pingsan, dan tidak sedikit kasus berakhir dengan kematian. Pestisida dalam bentuk cairan sangat berbahaya bagi kulit, karena dapat masuk ke dalam jaringan tubuh melalui ruang pori kulit (Girsang, 2009). Gangguan kulit akibat kerja yang sering dijumpai yaitu dermatitis kontak (Jeyaratnam \& Koh, 2010).

Di seluruh dunia, laporan tentang epidemiologi penyakit kulit akibat kerja dalam berbagai bidang pekerjaan spesifik relatif sedikit (Jeyaratnam \& Koh, 2010). Data Profil Kesehatan Indonesia 2008 menunjukkan bahwa distribusi pasien rawat jalan menurut International Classification of Diseases - $X$ (ICD-X) di rumah sakit di Indonesia tahun 2008 dengan golongan sebab sakit penyakit kulit dan jaringan subkutan terdapat sebanyak 115.100 jumlah kunjungan dengan 64.557 kasus baru (Kemenkes, 2009). Dua tahun setelahnya, yaitu pada tahun 2011 penyakit kulit dan jaringan subkutan menjadi peringkat ketiga dari 10 penyakit terbanyak pada pasien rawat jalan di rumah sakit se-Indonesia. Terdapat sebanyak 192.414 jumlah kunjungan dengan 48.576 kasus baru (Kemenkes, 2012). Hal ini menunjukkan bahwa penyakit kulit semakin berkembang dan masih sangat dominan terjadi di Indonesia.

Faktor-faktor yang mempengaruhi tingginya prevalensi penyakit kulit adalah iklim yang panas dan lembab yang memungkinkan bertambah suburnya jamur, kebersihan perorangan yang kurang baik dan faktor ekonomi yang kurang memadahi (Harahap, 2000). Penelitian yang dilakukan oleh Suhelmi, La Ane dan Manyullei (2014), pada petani rumput laut melaporkan bahwa 46, 2\% responden mengalami keluhan gangguan kulit dan 53,8\% responden masuk dalam kategori higiene perorangan yang tidak baik.

Data yang didapat dari laporan morbiditas pasien rawat jalan Puskesmas Cawas 1 pada bulan Desember 2014 terdapat sebanyak 349 jumlah kunjungan dengan diagnosa penyakit kulit dan jaringan subkutan lainnya. Penyakit kulit dan jaringan subkutan lainnya menduduki peringkat ke-5 dalam daftar 10 besar penyakit Puskesmas Cawas I. Dua bulan setelahnya, yaitu pada bulan Februari 2015 terjadi peningkatan jumlah kunjungan pasien menjadi 446 dan menduduki peringkat ke-3 dalam daftar 10 besar penyakit puskesmas Cawas I.

Dari study pendahuluan yang dilakukan di Kelurahan Nanggulan, dari 20 petani yang diwawancarai ditemukan 11 petani yang mengalami keluhan gangguan kulit. Data dari Balai Pengobatan Kelurahan Nanggulan, selama bulan Januari 2015 terdapat 37 kunjungan dengan keluhan gangguan kulit. Mayoritas pasien yang mengalami keluhan gangguan kulit bekerja sebagai petani. Keluhan subjektif bervariasi mulai dari rasa gatal ringan sampai nyeri pada daerah yang gatal. Dampaknya sangat dirasakan saat musim tanam dan musim panen tiba. Menurut tenaga kesehatan setempat, sebagian besar penyakit kulit disebabkan karena lingkungan sawah yang penuh dengan segala macam kotoran, penggunaan pestisida serta pola kebersihan petani yang kurang baik. Praktek kebersihan diri tidak diperhatikan oleh para petani, sebab kegiatan di lahan pertanian yang dilakukan 
sepanjang hari tidak memungkinkan untuk menjaga kebersihan diri. Dari pengamatan yang dilakukan pada saat jam makan siang, didapatkan sebagian besar petani menggunakan air ledeng yang mengalir dari sungai yang kotor untuk membersihkan diri sebelum istirahat untuk makan siang. Beberapa diantaranya juga menggunakan pakaian yang sama pada saat pergi ke sawah pada hari berikutnya. Dari hasil wawancara juga diketahui bahwa sesampainya di rumah, sebagian petani tidak langsung membersihkan diri tapi melepas lelah terlebih dahulu.

\section{METODE}

Penelitian ini merupakan penelitian kuantitatif non exsperimental yaitu survey analitik dengan rancangan cross sectional, yaitu suatu penelitian yang mencoba menggali bagaimana dan mengapa fenomena terjadi, serta mempelajari dinamika korelasi antara faktor- faktor risiko dengan efek, dengan cara pendekatan, observasi atau pengumpulan data sekaligus pada waktu yang bersamaan (Notoatmodjo, 2012). Penelitian dilakukan di Kelurahan Nanggulan dengan 89 responden yang merupakan petani padi yang berdomisili di Kelurahan tersebut. Teknik analisis data yang digunakan adalah teknik statistik, yakni teknik pengolahan data dengan menggunakan analisis statistik. Analisis bivariat menggunakan uji statistik Chi-Square. Chi-Square digunakan untuk mengetahui ada dan tidaknya hubungan antara variabel bebas dan variabel tergantung..

\section{HASIL PENELITIAN}

Distribusi responden berdasarkan jenis kelamin menunjukkan bahwa sebagian besar responden adalah laki-laki, yaitu sebanyak 53 responden (59,6\%) dan responden perempuan sebanyak 36 responden $(40,4$ $\%)$. Distribusi responden menurut umur menunjukkan distribusi tertinggi adalah responden yang berusia 45-54 tahun, yaitu sebanyak 17 responden (19,1 \%) dan distribusi terendah pada responden yang berusia $\geq 65$ tahun sebanyak 6 responden (3,4 \%).

Distribusi responden berdasarkan tingkat pendidikan menunjukkan bahwa distribusi tertinggi adalah responden yang tingkat pendidikannya SMA/ sederajat, yaitu sebanyak 44 responden $(49,4 \%)$ dan distribusi terendah terletak pada responden yang tingkat pendidikannya Diploma IV/ Strata I, yaitu sebanyak 1 responden (1,1\%). Distribusi berdasarkan riwayat alergi menunjukkan bahwa sebanyak 20 responden $(22,5 \%)$ memiliki riwayat alergi dan 69 responden $(77,5 \%)$ tidak memiliki riwayat alergi. Distribusi responden berdasarkan riwayat penyakit kulit menunjukkan bakwa sebanyak 8 responden $(9,0 \%)$ memiliki riwayat penyakit kulit dan 81 responden $(91,0 \%)$ tidak memiliki riwayat penyakit kulit. Sebanyak 16 responden (18\%) memiliki pola kebersihan diri dengan kategori buruk dan 73 responden ( $82 \%$ ) memiliki pola kebersihan diri dengan kategori baik. Sebanyak 58 responden $(65,2 \%)$ mempunyai gangguan kulit dan 31 responden $(34,8 \%)$ tidak mempunyai gangguan kulit. 
Tabel 1. Karakteristik Responden

\begin{tabular}{|c|c|c|}
\hline Karakteristik & Frekuensi & $\%$ \\
\hline \multicolumn{3}{|l|}{ 1. Jenis Kelamin: } \\
\hline Laki-laki & 53 & 59,6 \\
\hline Perempuan & 36 & 40,4 \\
\hline \multicolumn{3}{|l|}{ 2. Umur } \\
\hline 12-15 tahun & 1 & 1,1 \\
\hline 16-20 tahun & 15 & 16,9 \\
\hline 20-40 tahun & 34 & 38,2 \\
\hline 40-64 tahun & 33 & 37,1 \\
\hline$\geq 65$ tahun & 6 & 6,7 \\
\hline \multicolumn{3}{|l|}{ 3. Tingkat Pendidikan } \\
\hline $\begin{array}{l}\text { Tidak tamat SD/ Tidak } \\
\text { sekolah }\end{array}$ & 3 & 3,4 \\
\hline Tamat SD & 17 & 19,1 \\
\hline Tamat SMP & 22 & 24,7 \\
\hline Tamat SMA & 44 & 49,4 \\
\hline Tamat D III & 2 & 2,2 \\
\hline Tamat D IV/ S & 1 & 1,1 \\
\hline \multicolumn{3}{|l|}{ 4. Riwayat Alergi } \\
\hline Ya & 20 & 22,5 \\
\hline Tidak & 69 & 77,5 \\
\hline \multicolumn{3}{|l|}{ 5. Riwayat Penyakit Kulit } \\
\hline Ya & 8 & 9,0 \\
\hline Tidak & 81 & 91,0 \\
\hline \multicolumn{3}{|l|}{ 6. Pola Kebersihan Diri } \\
\hline Baik & 73 & 82,0 \\
\hline Buruk & 16 & 18,0 \\
\hline \multicolumn{3}{|l|}{ 7. Gangguan Kulit } \\
\hline Ya & 58 & 65,2 \\
\hline Tidak & 31 & 34,8 \\
\hline Total & 89 & 100 \\
\hline
\end{tabular}

Dari hasil analisa data SPSS didapatkan hasil yang menunjukkan bahwa responden dengan pola kebersihan baik yang mengalami gangguan kulit sebanyak 42 responden $(57,5 \%)$, dan yang tidak mengalami gangguan kulit sebanyak 31 responden (42, $5 \%$ ). Responden dengan pola kebersihan buruk seluruhnya mengalami gangguan kulit, yaitu sebanyak 16 responden (100\%). Hasil mengujian Chi Square diperoleh nilai $X^{2}$ hitung sebesar 10,426 lebih besar dari $X^{2}$ tabel sebesar 3,481 $(10,426>3,481)$ dengan $p$-value sebesar 0,001. Nilai p-value yang dihasilkan lebih kecil dari $0,05(0,001<0,05)$ sehingga ditolak. Berdasarkan hasil tersebut maka dapat diambil kesimpulan bahwa terdapat hubungan antara pola kebersihan diri dengan gangguan kulit pada petani padi di Kelurahan Nanggulan wilayah kerja Puskesmas Cawas I Kecamatan Cawas kabupaten Klaten. 
Tabel 2. Crosstab Hubungan antara Pola Kebersihan Diri dengan Gangguan Kulit pada Petani Padi di Kelurahan Nanggulan

\begin{tabular}{|c|c|c|c|c|c|c|c|}
\hline \multirow{3}{*}{$\begin{array}{c}\text { Pola } \\
\text { Kebersihan Diri }\end{array}$} & \multicolumn{4}{|c|}{ Gangguan Kulit } & \multirow{2}{*}{\multicolumn{2}{|c|}{ Total }} & \multirow{3}{*}{$P$ value } \\
\hline & \multicolumn{2}{|c|}{$\mathrm{Ya}$} & \multicolumn{2}{|c|}{ Tidak } & & & \\
\hline & Frekuensi & $\%$ & Frekuensi & $\%$ & Frekuensi & $\%$ & \\
\hline Baik & 42 & 57,5 & 31 & 42,5 & 73 & 100 & 0,001 \\
\hline Buruk & 16 & 100 & 0 & 0 & 16 & 100 & \\
\hline Total & 58 & 65,2 & 31 & 34,8 & 89 & 100 & \\
\hline $\begin{array}{l}X^{Z}=10,426 \\
\text { Kesimpulan }=H\end{array}$ & litolak & & & & & & \\
\hline
\end{tabular}

\section{PEMBAHASAN}

Hasil pengolahan data tabulasi silang (crosstab) menunjukkan bahwa 16 orang dari 89 responden dengan pola kebersihan diri kategori buruk semuanya (100\%) mengalami gangguan kulit. Dari uraian tersebut dapat diartikan bahwa pola kebersihan diri berpengaruh signifikan terhadap gangguan kulit. Banyak gangguan kesehatan yang diderita seseorang karena tidak terpeliharanya kebersihan perorangan dengan baik. Gangguan fisik yang sering terjadi adalah gangguan integritas kulit, gangguan membran mukosa mulut, infeksi pada mata dan telinga, dan gangguan fisik pada kuku (Riyadi \& Harmoko, 2012).

Fenomena yang terjadi di lingkungan petani Kelurahan Nanggulan, yaitu banyak petani yang tidak memperhatikan kebersihan dirinya. Salah satu contohnya banyak petani yang sering menggunakan air sungai (air yang tidak bersih) untuk membersihkan diri selama di sawah. Selain itu banyak petani yang tidak langsung membersihkan diri sesampainya di rumah. Menurut Kozier et al (2011), kebersihan diri seseorang dipengaruhi oleh beberapa faktor, diantaranya adalah budaya, agama, lingkungan, tahap perkembangan, kesehatan dan energi, serta pilihan personal. Di lingkungan petani padi di Kelurahan Nanggulan pengaruh lingkungan sangat erat dengan kegiatan kebersihan diri. Tidak adanya sumur atau sumber air bersih di setiap lahan persawahan membuat para petani menggunakan air sungai untuk membersihkan diri sebelum pulang ke rumah. Pilihan personal juga mempengaruhi kegiatan kebersihan diri, sesampainya di rumah sebagian besar petani lebih suka memilih istirahat terlebih dahulu sebelum membersihkan diri.

Hasil di atas sejalan dengan penelitian yang dilakukan oleh Suhelmi, Ruslan dan Syamsuar (2014) tentang hubungan antara higiene perorangan dengan keluhan gangguan kulit pada petani rumput laut di Kelurahan Kalumeme Kecamatan Ujung Bulu Kabupaten Bulukumba, yang menunjukkan bahwa ada hubungan antara hygiene perorangan dengan keluhan gangguan kulit pada petani rumput laut.

Pada analisis penelitian pola kebersihan diri dengan kategori baik didapatkan hasil bahwa sebanyak 31 responden (42,5\%) tidak mengalami gangguan kulit, sedangkan 42 responden $(57,5 \%)$ mengalami gangguan kulit. Dari hasil tersebut diketahui bahwa lebih dari $50 \%$ responden dengan pola kebersihan diri kategori baik ternyata mengalami gangguan kulit.

Gambaran hasil penelitian di atas terlihat bahwa, walaupun dengan pola kebersihan diri yang baik masih didapatkan gangguan kulit. Dari hasil tersebut dapat disimpulkan bahwa gangguan kulit tidak hanya dipengaruhi oleh pola kebersihan diri saja. Terdapat faktor lain yang menyebabkan terjadinya gangguan kulit, diantaranya adalah umur, hidrasi, iklim, infeksi dan lingkungan kerja. Menurut Maryam dkk (2008), semakin bertambahnya usia kulit menjadi semakin kering dan keras, maka indra peraba di kulit semakin peka. Sensitivitas terhadap sakit dapat terjadi akibat penurunan 
ketahanan terhadap rasa sakit. Rasa sakit tersebut berbeda untuk setiap bagian tubuh.

Berdasarkan penelitian yang dilakukan oleh Aisyah, Santi dan Chahaya (2013), tentang hubungan hygiene perorangan dan pemakaian alat pelindung diri dengan keluhan gangguan kulit pada pekerja pengupas udang di Kelurahan Pekan Labuhan Kecamatan Medan Labuhan Tahun 2012. Hasil uji chisquare variabel umur $(\mathrm{p}=0,000)$, terdapat hubungan yang bermakna dengan keluhan gangguan kulit. Variabel yang tidak berhubungan dengan keluhan gangguan kulit adalah variabel kebersihan kulit sehari-hari dan kebersihan kuku. Hal tersebut menunjukkan bahwa umur berpengaruh signifikan terhadap keluhan gangguan kulit pada pekerja pengupas udang.

Lingkungan kerja juga memegang peranan utama dalam perkembangan gangguan kulit akibat kerja (Jeyaratman \& Koh, 2010). Matahari, angin, penyebab alergi, dan agen infeksi di lingkungan dan juga iritan kimia (bahan pencelup, detergen, tumbuhan, dst) semua berpotensi menyebabkan kerusakan kulit (Vaughans, 2013). Selain itu juga terdapat berbagai antropoda yang berada di persawahan. Menurut Kumar et al (2010), antropoda adalah hewan yang ditemukan di mana- mana dan kita semua rentan terkena gigitan, sengatan dan berbagai kelainan lain. Antropoda mencakup arachnida, insecta, dan chilopoda. Semua dapat menyebabkan lesi kulit, tetapi pola klinis reaksinya dapat sangat bervariasi. Sebagian orang hanya mengalami sedikit gejala, yang lain mengalami

ketidaknyamanan yang mengganggu.

Indikator kesehatan lingkungan menurut DEPKES RI 2007 dalam Efendi \& Makhfudli (2009), lingkungan merupakan salah satu variabel yang kerap mendapat perhatian khusus dalam menilai kondisi kesehatan masyarakat. Bersama dengan faktor perilaku, pelayanan kesehatan dan genetik, lingkungan menentukan baik buruknya status derajat kesehatan masyarakat. Dewasa ini, manajemen pengolahan limbah padat merupakan tantangan terbesar yang harus dihadapi bidang kesehatan masyarakat. Masalah yang tetap akan menjadi tantangan adalah masalah pembuangan yang tepat untuk sampah dan limbah padat lain. Tingkat paparan pestisida dan insektisida di lingkungan kerja pertanian juga menjadi faktor penentu baik buruknya status derajat kesehatan masyarakat.

Banyak fenomena yang terjadi di lingkungan kerja petani di Kelurahan Nanggulan, diantaranya yaitu didapatkan banyaknya petani yang menggunakan pestisida dan insektisida tanpa mengetahui takaran dan kegunaannya. Menurut mereka semakin banyak menggunakan pestisida akan menghindarkan padi dari serangan hama. Walaupun tidak ada hama yang menyerang, para petani tetap menggunakan pestisida dengan dalih untuk mencegah serangan hama. Selain itu masih banyaknya warga yang membuang sampah ke sungai dan perairan di sekitar lahan persawahan membuat kondisi air di persawahan sangat kotor dan tercemar.

Penelitian Ismy, Ashar \& Dharma (2012), tentang analisis kualitas air dan keluhan gangguan kulit pada masyarakat pengguna air sungai Siak di Pelabuhan sungai Duku Kelurahan Tanjung Rhu Kecamatan Limapuluh Kota Pekanbaru tahun 2012, menunjukkan bahwa terdapat hubungan antara sumber air yang tercemar dengan gangguan kulit, penggunaan sumber air tercemar sebagai sumber air dapat menyebabkan berbagai macam gangguan penyakit, salah satu diantaranya adalah gangguan kulit.

\section{KESIMPULAN}

Diketahui sebanyak 16 responden memiliki pola kebersihan diri yang buruk. Sisanya sebanyak 73 responden memiliki pola kebersihan diri dengan kategori baik. Pada saat dilakukan pengumpulan data diketahui bahwa sebanyak 58 responden mengalami gangguan kulit. Sisanya 31 responden tidak mengalami gangguan kulit. Terdapat hubungan antara pola kebersihan diri dengan terjadinya gangguan kulit pada petani padi di Kelurahan Nanggulan wilayah kerja Puskesmas Cawas I Kecamatan Cawas kabupaten Klaten 
Saran penelitian ini bagi petani diharapkan dapat meningkatkan pola kebersihan diri, memahami pentingnya menjaga kebersihan lingkungan serta menggunakan bahan-bahan pestisida sesuai petunjuk. Sehingga kedepannya dapat menurunkan angka kejadian gangguan kulit di Kelurahan nanggulan. Bagi pemerintah desadiharapkan dapat memfasilitasi petani dalam mendapatkan informasi tentang kesehatan, lingkungan serta penggunaan pestisida yang aman. Bagi peneliti hendaknya menganalisis tentang faktor-faktor yang belum ada dalam penelitian ini dan juga dampak pestisida bagi kesehatan kulit.

\section{DAFTAR PUSTAKA}

Aisyah F., Santi D.N., \& Chahaya, I. (2013). Hubungan Hygiene Perorangan dan Pemakaian Alat Pelindung Diri dengan Keluhan Gangguan Kulit pada Pekerja Pengupas Udang di Kelurahan Pekan Labuhan Kecamatan Medan Labuhan Tahun 2012. Lingkungan dan Kesehatan Kerja (Vol. 2, No. 2). Diakses 19 Januari 2015. http://portalgaruda.org/inde x.php?ref=browse\&mod=vi ewarticle\&article $=51450$

BPS. (2014). Laporan Bulanan Data Sosial Ekonomi (Edisi 55). Diakses 25 Januri 2015.http://www.bps.go.id/i ndex.php/publikasi/ downloadFile/425

Efendi F \& Makhfudli. (2009). Keperawatan Kesehatan Komunitas: Teori dan Praktik dalam Keperawatan. Jakarta: Salemba Medika

Girsang, Warlinson. (2009). Dampak Negatif Penggunaan Pestisida. Diakses 27 Januari 2015. https://usitani.wordpress.co $\mathrm{m} /$ category/ agroteknologi/

Haerani. (2010, 1 Juli). Penerapan Keselamatan dan Kesehatan Kerja di Bidang Pertanian di Indonesia. Media Kesehatan Masyarakat Indonesia (Vol. 6, No. 3). Diakses 23 Desember 2014. http://portalgaruda.org/indcl eex.php? ref=browse\&mod=viewartic le\&article=16579

Harahap, Marwali. (Ed.). (2000). Ilmu Penyakit Kulit. Jakarta: Hipokrates

Ismy F., Ashar T., \& Dharma, S. (2013, 31 Mei). Analisis Kualitas Air dan Keluhan Gangguan Kulit pada Masyarakat Pengguna Air Sungai Siak di Pelabuhan Sungai Duku Kelurahan Tanjung Rhu Kecamatan Limapuluh Kota Pekanbaru Tahun 2013. Jurnal Lingkingan dan Keselamatan Kerja (vol 2, No 3). Diakses Tanggal 28 April 2015. httpejournal.litbang.depkes. go.idindex.phpjekarticleview $\underline{1690 \mathrm{pdf}}$

Jeyaratnam, \& Koh, D. (2010). Buku Ajar Praktek Kedokteran Kerja (Suryadi, Penerjemah). Jakarta: EGC

Kementerian Kesehatan RI. (2009). Profil Kesehatan Indonesia Tahun 2008. Jakarta: Kementerian Kesehatan. Diakses 17 Nopember 2014. http:// www.depkes.go.id/resource s/download/pusdatin/profil- kesehatan-indonesia/profil- kesehatan-indonesia- 2008.pdf.

Kumar V., Abbas A.K. \& Fausto, N. (2010). Patologi Penyakit (Brahm U. Pendit, Penerjemah) (Edisi 7). Jakarta:EGC

Kozier B., Erb G., Berman A. \& Snyder, S.J. (2011). Buku Ajar Fundamental Keperawatan: Konsep, Proses dan Praktek (Pamilih Eko Karyuni dkk, Penerjemah) (Edisi 7, Vol. 2). Jakarta: EGC

Maryam R.S., dkk. (2008). Mengenal Usia Lanjut dan Perawatannya. Jakarta: Salemba Medika

Notoatmodjo, Soekidjo. (2005). Metode Penelitian Kesehatan. Jakarta: PT Rineka Cipta

Riyadi, S. \& Harmoko. (2012). Standard Operating Prosedure dalam Praktek Klinik Keperawatan Dasar. Yogyakarta: Pustaka Pelajar

Suhelmi R., La Ane R. \& Manyullei, S. $\quad$ (2014, 22 Agustus). Hubungan Masa Kerja, Higiene Perorangan dan Penggunaan Alat Pelindung Diri dengan keluhan Gangguan Kulit Petani Rumput Laut di Kelurahan Kalumeme Bulukumba. Diakses 19 Januari 2015. http://repository.unhas.ac.id/handle/123456789/10693 
Vaughans, Bennita W. (2013). Keperawatan Dasar (Th. Arie

Prabawati, Penerjemah). Yogyakarta: Rapha Publishing

Wibowo, Daniel S. (2008). Anatomi tubuh manusia. Jakarta : PT. Grasindo 